\title{
Validation of the Serbian Translation of the Disgust Propensity and Sensitivity Scale (DPSS)
}

\author{
Nikola Rokvić \\ Union University, Faculty for Legal and Business Affairs Dr Lazar Vrkatić, \\ Novi Sad, Serbia
}

\begin{abstract}
Disgust represents a feeling of revulsion and is manifested as a response to adverse stimuli and indicates a motivation to withdraw from the stimulus. Several attempts were made to measure disgust, the earliest being the Disgust Sensitivity Scale (Haidt et al., 1994) that relied on responses to disgust elicitors, and the Disgust Propensity and Sensitivity Scale (DPSS, Cavanagh \& Davey, 2000) that focused on the feeling itself, not on the strength of the reaction to specific disgust elicitors. There are two proposed models of the DPSS, one with two subscales, disgust propensity (DP) and disgust sensitivity (DS), and the other with three subscales where the self-focused/ruminative disgust (SFR) split from DS. This study aimed to validate the Serbian translation of the scale. We used two samples, a student sample $(N=437)$ and a social network user sample $(N=344)$. We used confirmatory factor analysis in both samples and the yielded results have shown that the three-factor solution is superior. The internal consistency of the subscales was marginally acceptable, while SFR subscale alpha value lagged in the social network user sample. Significant gender differences in subscale values were detected as expected, adding to the scale validity. Also, DP and DS registered a weak positive correlation with trait Neuroticism, negative affect, stress, depression, and anxiety. These results will further our claims that our translation of the DPSS is valid. In conclusion, we believe that the Serbian translation of the 12 item DPSS scale is viable for use in future research on this subject.
\end{abstract}

Keywords: disgust sensitivity, disgust propensity, DPSS, validation

\section{Introduction}

Disgust can be defined as a feeling of revulsion manifesting itself as an answer to an aversive stimulus that induces motivation to withdraw from that stimulus (Rozin et al., 2000). It is proposed that disgust evolved functioning as a mechanism that facilitates disease avoidance (Shook et al., 2017). When one thinks of something disgusting, it is most likely that a food-related event will come to mind first (Vicario

Nikola Rokvić, Novosadskog sajma 29, 21000 Novi Sad, Serbia, E-mail: nikolamrokvic@gmail.com 
et al., 2017). In fact "disgust, an originally food-related emotion, expanded, both in biological and in cultural evolution, to become a guardian of the body, the social order, and the sole" (Rozin et al., 2008, p. 9-26). Concurrently psychoanalysis theorizes that disgust is recognized in the faces of parents and other significant figures in early development since they use it more often than they presume in response to certain behaviors and bodily functions of the child (Miller, 2004). Also, this author postulated that facial recognition of disgust in certain social situations later prompts a conditioned response to the same situation.

Relationship between disgust and psychopathology has been heavily investigated. For instance, descriptive and experimental research has implicated disgust in the development and maintenance of fear of the spiders (arachnophobia), fear of the blood/injection injury, contamination-based obsessive-compulsive disorder and eating disorders (Olatunji et al., 2007). Also, individuals suffering from emetophobia, fear of vomiting, have significantly elevated levels of disgust sensitivity; and propensity and disgust sensitivity are good predictors of emetophobic complaints (van Overveld et al., 2008). Mental contamination, a fear of contamination that arises in the absence of physical contact with a perceived contaminant, is positively connected to both disgust propensity and disgust sensitivity (Travis \& Fergus, 2015). Also, disgust propensity increases the risk of developing a negative body image by increasing the feeling of self-disgust while disgust sensitivity increases the impact of self-disgust on the development of a persistent negative body appraisal (von Spreckelsen et al., 2018). Furthermore, there is a significant positive association between disgust propensity and sensitivity and hypochondriasis and health anxiety (Olatunji, 2009). There is also research implying a connection between disgust, schizophrenia, depression, and various sexual dysfunctions (Olatunji \& McKay, 2007). Disgust has also been strongly related with the existence of reactive formation, a psychological defence mechanism, in an individual (Miller, 2004). In light of what was mentioned above, it is safe to say that disgust as a trait is linked to the psychopathology in many forms and that the precise mechanisms are still the subject of much debate and research. Given such documented relationships between disgust and psychological distress factors, we have decided to determine the relationship between disgust and measures of wellbeing, such as subjective vitality and life satisfaction. Apart from the research values of this approach, we also believe it is valuable to determine the validity of the instruments used.

On a neurological level, disgust-eliciting pictures have been shown to activate several areas of the brain such as the parietal cortex, anterior cingulate cortex and brain regions involved in valence and arousal processing such as the insula (Schafer et al., 2009). There is research supporting the hypothesis that the insula is, in fact, a hub for disgust sensitivity related behaviour, while other parts of the brain may be linked to specific facets of disgust sensitivity (Vicario et al., 2017). The authors also suggest that the neural basis of disgust and emotional processing largely overlap with 
those underpinning the sense of internal bodily signals, including visceral sensations. When shown disgust-eliciting video clips, subjects have shown increased activation of the parasympathetic and the sympathetic autonomous nervous system (de Jong et al., 2011).

Interestingly enough, female participants consistently measure higher levels of disgust than males (Druschel \& Sherman, 1999). There have been attempts to explain these differences in several different disgust domains (Al-Shawaf et al., 2018). When considering sexual disgust, authors suggest that greater minimum obligatory parental investment, higher likelihood and greater cost of sexually transmitted diseases, defence against rape and sexual coercion, and sex differences in reputational damage might be the cause of greater sexual disgust levels in females. When considering pathogen disgust, the authors also offer several hypotheses such as danger of offspring contagion, the teaching and modelling hypothesis where mothers teach offspring disease-avoidant behaviour and so it is more pronounced, and the food preparation hypothesis were for most of the history women have been tasked with cleaning and preparing food. Also, there have been reported differences in disgust sensitivity with regards to age with older individuals displaying decreased disgust sensitivity (Curtis et al., 2004).

The interest in researching disgust does not stop at the level of the psychopathological - social implications of trait disgust have also been a subject of great interest. There is a strong relation between political conservativism and disgust sensitivity, even when controlled for the Big Five personality traits (Inbar et al., 2012). Following these conclusions, disgust sensitivity has been shown to predict intuitive disapproval of homosexual behaviour (Inbar et al., 2009). This incursion of the emotion of disgust in the field of morality has been of great interest to researchers. When disgust is elicited in individuals, they tend to make harsher moral judgements (Schnall et al., 2008). It has been shown that, indeed, irrelevant feelings of disgust influence moral judgements, especially when this feeling has been induced by oral/gustatory interventions, but also caution against strong categorical conclusions based on these findings (Landy \& Goodwin, 2015). In that respect, some findings insist that "moral disgust" is not a function of disgust sensitivity as such, but just one instantiation of a more general association between affect and judgement (Landy \& Piazza, 2017). But still, some studies report very specific relationships between disgust sensitivity and moral judgement, especially in the domain of transgressions in the domain of purity morality (Wagemans et al., 2019). As we have shown, research into the relationship between disgust sensitivity, morality, and moral judgement is diverse, on-going and at times inconclusive, but a very exciting and vibrant field of study. 


\section{Disgust Propensity and Sensitivity Scale}

The oldest instrument of measuring disgust is the Disgust Sensitivity Scale, and its items revolve around measuring responses to various disgust elicitors (Haidt et al., 1994). One of the more widely used scales is the Three Domain Disgust Scale, which measures pathogen, sexual and moral disgust (Tybar et al., 2009). The Disgust Propensity and Sensitivity Scale (DPSS), first proposed by Cavanagh and Davey (2000), intended to measure both disgust sensitivity and propensity but without items that have significant similarities to those that imply psychopathology. Devoid of mentioning specific elicitors in its proposed items, disgust sensitivity (DS) and disgust propensity (DP) have been isolated as separate constructs in the DPSS with different associations with related constructs (van Overveld et al., 2006). In this manner, disgust sensitivity can be interpreted as a measure of how inconvenienced a person is by experiencing disgust and disgust propensity can be seen as readiness or the ease with which a person reacts with disgust.

It was further refined by van Overveld et al. (2006). The authors shortened the scale from 32 to 16 items, and this structure was further validated by Olatunji et al. (2007). However, work on the scale was not yet done, and further examination of the scale resulted in another reduction to a 12-item scale but retaining the same structure - the disgust propensity and disgust sensitivity subscales (Fergus \& Valentiner, 2009). Further research has put the two-factor structure of the questionnaire into doubt (Goetz et al., 2013). The authors detected a third, lower-order factor that they named self-focused/ruminative disgust (SFR). We have found literature regarding translating the DPSS-r on other languages, and while it retained its original structure in Japanese (Iwasa et al., 2016) and in Portuguese (Ferreira et al., 2016), the Italian translation of the 16-item version of the scale yielded a 4-factor solution (Mrtoni et al., 2017). As it can be seen, work on this scale is vibrant and continuously offers possibilities for improvement in order to detect the measured constructs more specifically.

Our study aimed to validate the Serbian translation of the reduced item (12item) Disgust Sensitivity and Propensity Scale Revised, determine its structure and relationship with other relevant constructs. The primary focus of this research was to test the available structural models by using confirmatory factor analysis. For this purpose, we have conducted two studies - in Study 1, we have used a sample of undergraduate students to verify proposed construct validity and cross-check it with personality and measures of psychological well-being, and in Study 2, we used a proposed general population sample to recheck construct validity and determine its relationship with factors of psychological distress. 


\section{Study 1}

\section{Method}

\section{Participants}

The first study consists out of 437 participants ( $82.4 \%$ female) with a mean age of $20.51(S D=1.25 ; \min =19 ; \max =26)$. All of the participants were undergraduate students participating voluntarily in the survey without any incentive or reward.

\section{Instruments}

Subjective Vitality Scale (SVS, Nix et al., 1999) - Developed under the auspices of the Self-Determination theory (SDT), the concept of vitality was proposed as a state connected to, and possibly arising from, the satisfaction of basic psychological needs, as they are defined by this theory (Nix et al., 1999). We used the most commonly utilized 6-item version (Bostic et al., 2000) that measures responses on a 7-points scale (1 - Not true at all, and 7 - Very true; e. g. I feel alive and vital). It showed good internal consistency in our study, with an alpha score of .83.

Satisfaction With Life Scale (SWLS, Diener et al., 1985), a 5-item scale, has shown remarkable effectiveness over decades since proposed by Diener and associates in 1985, and so has the Serbian translation (Jovanović, 2016; Vasić et al., 2011). The responses are measured on a 5-point scale (1 - Strongly disagree, and 5 - Strongly agree; e. g. I have been satisfied with my life), and this is a single construct scale. In our research it has shown acceptable internal consistency of $\alpha=.77$.

Mini International Personality Item Pool - 6 (IPIP-6, Sibley, 2012) - a short 24-item measure for the HEXACO six dimensions personality model with responses measured on a 7-point scale (1 - Strongly disagree, and 7 - Strongly agree; e. g. I am not interested in abstract ideas). We only used 20 items which cover the subscales that corresponds to the Big Five personality traits (Medjedović \& Tara, 2017). The subscales showed lower but acceptable internal consistency levels ( $\alpha$ ranging from .64 to .75).

\section{Procedure}

We have decided to compare the original 2-factor model proposed by Fergus and Valentiner (2009) (Model 1) and the alternative 3-factor model proposed by Goetz and associates (2013) (Model 2). When performing confirmatory factor analysis, we used the maximum likelihood estimator in SPSS Amos version 21 program. We have used the following model fit indicators: Root Mean Square Error of Approximation (RMSEA), Comparative Fit Index (CFI), Tucker Lewis Index 
(TLI), Akaike Information Criterion (AIC) and the Bayesian Information Criterion (BIC).

One of the indicators of a good model fit that we used is RMSEA. We placed the maximum cutoff value to be .08 , while we considered $<0.05$ to reflect a good model fit (Browne \& Cudeck 1993). Next, we used the CFI and the TLI in order to determine a good model fit. For both indices we considered values of at least .90 to indicate an acceptable model fit, while values of .95 and above represent a good model fit (Bentler, 1990; Tucker \& Lewis, 1973). The last two observed parameters were the AIC and the BIC where models with lower AIC and BIC are considered to be indicators of better model fit (Akaike, 1987; Schwatz, 1978). These parameters we considered useful when comparing to contesting models of how the instrument can be structured. Because there is only a small number of male participants it was impractical to perform confirmatory factor analysis on male and female subsamples. Also, to further corroborate the validity of the scale, we tested it along with related constructs and further explored its relationships with constructs that did not find precedent for in available literature. For the same reason, we have tested gender differences in the DPSS subscales.

\section{Results}

Results of the confirmatory factor analysis are displayed in Table 1 . For the first model the $\chi^{2}$ value was $218.14(d f=53 ; p<.001)$, for the second model we have found the following $\chi^{2}$ value $153.91(d f=51 ; p<.001)$. When analysing our findings, we can see that when considering all observed parameters for the second model, the 3 -factor model proposed by Goetz and associates (2013) is superior to the original 2factor model. Taking this into account, we have performed all further analyses by using this structure model.

Table 1.

Results of Confirmatory Factor Analysis for Study 1

\begin{tabular}{lccccc}
\hline & RMSEA & CFI & TLI & AIC & BCI \\
\hline Model 1 & .085 & .903 & .879 & 268.14 & 370.14 \\
Model 2 & .068 & .939 & .922 & 207.91 & 318.07 \\
\hline
\end{tabular}

Note. Model 1 represents a 2-factor solution with DP and DS, Model 2 represents a 3-factor solution with DP, DS and SFR.

The DPSS-r subscales Disgust Propensity, Disgust Sensitivity and Self and Ruminative Disgust (DP, DSs and SFR respectively) have shown good overall consistency in Study 1 ( $\alpha$ values of $.81, .79$ and .62 respectively). Correlations between measured constructs were mostly weak and insignificant. The only significant correlations at the level of $p<.01$ were those between Neuroticism and $\mathrm{DP}(r=.17)$ and DS $(r=.16)$, while SFR correlated negatively with Agreeableness 
$(r=-.1)$ and Openness $(r=-.12)$ at the significance level of $p<.05$. These correlations, while statistically significant, are very low. With regards to gender, we found that there were significant differences $(p<.05)$ in both DP $\left(M_{\mathrm{f}}=18.94 ; S D_{\mathrm{f}}=\right.$ 5.5 and $M_{\mathrm{m}}=17.35 ; S D_{\mathrm{m}}=4.93$ female and male respectively, $\left.\mathrm{t}(d f)=2.34(435)\right)$ and DSs $\left(M_{\mathrm{f}}=10.49 ; S D_{\mathrm{f}}=3.68\right.$ and $M_{\mathrm{m}}=9.56 ; S D_{\mathrm{m}}=3.51$ female and male respectively, $\mathrm{t}(d f)=2.2(435))$ with females registering higher levels, but there is no gender difference in SFR levels $\left(M_{\mathrm{f}}=4.33 ; S D_{\mathrm{f}}=1.9\right.$ and $M_{\mathrm{m}}=4.39 ; S D_{\mathrm{f}}=2.06$ female and male respectively, $\mathrm{t}(d f)=-.23(435))$. We have performed linear regression to determine the percentage of DPSS subscales variance determined by the Big Five personality traits. In case of DP $(F(d f)=3.76(436) ; p=.002)$ it is only $4.2 \%$, DSs $(F(d f)=2.6(436) ; p=.025)$ it was $2.9 \%$ and SFR $(F(d f)=2.26(436) ; p$ $=.048)$ it was only $2.6 \%$.

\section{Study 2}

\section{Method}

\section{Participants}

The second study had 344 participants ( $74.4 \%$ declared themselves as female) with a mean age of $27.8(S D=8.42 ; \min =18 ; \max =61)$. This study was performed via internet, and the survey freely circulated the social networks. With regard to education levels, $152(44.2 \%)$ reported themselves as students, $80(23.3 \%)$ as having finished undergraduate studies, $35(10.2 \%)$ have high-school level education, $64(18.6 \%)$ have master's level education and $12(3.8 \%)$ have $\mathrm{PhD}$ level education. With regards to employment status, $129(37.5 \%)$ are students, $61(17.7 \%)$ are unemployed, $47(13.7 \%)$ are precariously employed and $107(31.1 \%)$ are permanently employed.

\section{Instruments}

Positive and Negative Affect Schedule (PANAS, Watson et al, 1988) - In our study we only used the negative affect schedule of this inventory (Mihić et al., 2014). This is a 10-item subscale, measuring responses on a 5-point scale (1 - Strongly disagree; 5 -Strongly agree), that showed excellent internal consistency with an $\alpha$ value of .88 .

General Anxiety Disorder 7 scale (GAD7, Spitzer et al., 2006) - was conceived as a short scale for measuring general anxiety as represented by a feeling of constant worry. It has no subscales, consisting only of 7 items that measure responses on a 4point scale (1 - Not at all; 4 - Nearly every day). Its reliability in Serbian has been proven (Rokvić, 2019) and has shown good internal consistency with $\alpha=.88$. 
Depression Anxiety and Stress Scale 21 (DASS21, Henry, 2011) - consists out of 21 items and three subscales that measure levels of stress, anxiety and depression with 7 items each, measuring responses on a 4-point scale (1 - Does not apply to me at all, 4-Applies to me very much or most of the time), and it was validated on the Serbian language and shown good psychometric properties (Jovanović et al., 2014). The subscales showed good internal consistency with $\alpha$ ranging from .87 to .88 .

The Big Five Inventory (McCrae \& Costa, 1999) - Is a 44-item inventory of the Big Five personality traits measuring responses on a 5-point scale $(1-$ Completely disagree, 5 - Strongly agree). In our research, we have only used the Neuroticism subscale (McCrae \& Costa, 1999). The Neuroticism subscale has shown tolerable internal consistency of $\alpha=.69$.

\section{Procedure}

We have repeated the confirmatory factor analysis procedure on this sample to determine the factor structure of the questionnaire by using the same models as in Study 1 . The same program, procedure, estimator indexes and cutoff values were used in this study as were used in Study 1 . We were interested in seeing the results of this repeated procedure, since Study 2 represents a more diverse sample of the population, not just undergraduate students, and the effect, if any, that this can have on the validity of the factor structure. Because there is also a small number of male participants in Study 2, it was impractical to perform confirmatory factor analysis on male and female subsamples. We have also used methods of descriptive statistics, correlation, and ANOVA.

\section{Results}

The results of the confirmatory factor analysis in Study 2 are presented in Table 2. Again, using the criteria proposed in Study 1, we determined that the second model, the one containing the SFR subscale, has a superior model fit. The DPSS-r subscales Disgust Propensity, Disgust Sensitivity and Self and Ruminative Disgust (DP, DSs and SFR respectively) have shown acceptable internal consistency in Study 2 ( $\alpha$ values of .78, .77 and .51 respectively).

Table 2.

Results of Confirmatory Factor Analysis of the Proposed Models in Study 2

\begin{tabular}{ccccccc}
\hline & $\mathrm{X}^{2}(d f) ; p$ & RMSEA & CFI & TLI & AIC & BIC \\
\hline Model 1 & $219.711(53) ; p<.001$ & .096 & .857 & .822 & 269.711 & 365.727 \\
Model 2 & $127.369(50) ; p<.001$ & .067 & .934 & .913 & 183.269 & 290.807 \\
\hline
\end{tabular}

Note. Model one represents a 2-factor solution with DP and DS, Model 2 represents a 3-factor solution with DP, DS and SFR. 
The results of correlations between measured constructs in Study 2 and the three subscales model of the DPSS-r are presented in Table 3.

Table 3.

Correlations Between Measured Constructs in Study 2

\begin{tabular}{lllc}
\hline & DP & DSs & SFR \\
\hline GAD7 & $.16^{* *}$ & $.27^{* *}$ & $/$ \\
Neuroticism & $.15^{* *}$ & $.29^{* *}$ & $.11^{*}$ \\
Negative affect & $.19^{* *}$ & $.25^{* *}$ & $.19^{* *}$ \\
Stress (DASS21) & $.14^{* *}$ & $.26^{* *}$ & $.11^{*}$ \\
Depression (DASS21) & $.17^{* *}$ & $.11^{*}$ & $/$ \\
Anxiety (DASS21) & $.17^{* *}$ & $.30^{* *}$ & $.14^{*}$ \\
\hline
\end{tabular}

${ }^{*} p<.05 ;{ }^{* *} p<.01$.

The same gender difference in DPSS subscale values was found in the general population sample, Study 2, for DP $\left(M_{\mathrm{f}}=21.72 ; S D_{\mathrm{f}}=4.63\right.$ and $M_{\mathrm{m}}=19.53 ; S D_{\mathrm{m}}=$ 5.29 female and male respectively, $t(d f)=3.68(342))$ and DSs $\left(M_{\mathrm{f}}=10.67 ; S D_{\mathrm{f}}=\right.$ 3.97 and $M_{\mathrm{m}}=8.1 ; S D_{\mathrm{m}}=2.99, t(d f)=4.51(342)$ ) with $p$ values less than .001 in both cases. In Study 2, there was also no difference in SFR levels between genders $\left(M_{\mathrm{f}}=\right.$ 4.06; $S D_{\mathrm{f}}=1.8$ and $M_{\mathrm{m}}=3.95 ; S D_{\mathrm{m}}=1.87$ female and male respectively, $t(d f)=$ $.463(342))$. With regards to employment status, we performed ANOVA analysis on the Study 2 sample. For DP ANOVA was not significant $(p=.51)$, for DSs $(F(d f)=$ $2.87(343) ; p=.036)$ there was a significant difference between students and permanently employed, with the latter having lower levels of disgust sensitivity. For SFR $(F(d f)=3.23(343) ; p=.023)$ the findings are the same as for DSs. When performing ANOVA to determine possible differences between education groups, we excluded those participants with a $\mathrm{PhD}$ because of how few there were in our sample. ANOVA was not significant for any of the DPSS subscales. In this sample DP, DSs and SFR values do not correlate significantly with participant age.

\section{General Discussion}

Given the designated criteria for the goodness of fit, we can safely say that the 3 -factor mode, the one that splits the Disgust Propensity and Sensitivity Scale (DPSS) into disgust propensity (DP), disgust sensitivity (DSs) and selffocused/ruminative disgust (SFR) subscales, has proven to be better than the 2-factor model. But we must observe that both models, although achieving acceptable values of observed estimator indices, fell short of proposed good model fit values. In Study 1 , the 2-factor model failed to achieve acceptable values on the RMSEA and TLI criteria, and this was also the case for CFI on the general population sample (Study 
2). All observed parameters of goodness of fit regarding the 3-factor model are placed within acceptable parameters on both samples.

When we compare our results to the original Study proposing the 12-item 2factor model, the results are somewhat inconclusive, with our results being better on the RMSEA criterion, but slightly underachieving on the CFA criterion (Fergus \& Valentiner, 2009). On the other hand, the situation with model 2 is quite the opposite. In fact, given that Goetz and associates (2013) used less stringent criteria for goodness of fit on estimators that we have used in our study, we can safely say that in our research the 3-factor model outperformed the original study on every observed estimator. Considering all this, we believe we can say that when confirmatory factor analysis is concerned, the 3-factor model of the DPSS is superior to the 2-factor model and we recommend it for use in further research.

The internal consistency of the scale has been in line with what we were led to expect by Ferguson (2009), in other words, acceptable, just under the .80 cutoff alpha value. Goetz and associates (2013) were the first to isolate the SFR subscale and in its inception, it already had a lower than acceptable alpha value. Concordantly, the internal consistency values of SFR in study one of four research are in accordance with what we are led to expect from Goetz and associates (2013). We believe that this is partly because both observed studies used a student sample. Study two, in our case, consisted of social network users, a more diverse group of participants, therefore, we believe this to be the reason why there is a discrepancy between SFR alpha value recorded in Study 2 on one hand and study two and results found by Goetz and associates (2013) on the other.

The existence of gender differences in results, with higher levels of DS and DP in female participants, goes towards the validity of the scale translation. Although we did not find particular reference to gender disparity in DPSS scores, a large body of work using other scales and methodologies has determined that females have higher levels of disgust sensitivity (Al-Shawaf et al., 2018; Prokop \& Janciovicova, 2013). Therefore, the lack of gender differences reported in both available literature that used DPSS and our research is puzzling and at present cannot be explained. In our research we must take into account the fact that our samples consist mostly of female participants and that this might impact our results. Although unexpected, the fact that our results are in line with literature regarding the examined scale goes to further our claims to the validity of our translation.

We have not found any significant correlation between any of the DPSS subscale values and age, with older individuals being less sensitive to disgust. However, this connection has been reported in literature (Curtis et al., 2004). We believe we can explain this lack of result with the properties of the samples used in our study. Both samples have a rather low average age (20.51 and 27.8 years of age). This "lack" of older participants prohibits us from fully testing the age hypothesis. Therefore, this discrepancy with literature findings cannot be considered as an 
argument against the scale's validity but an artefact of the sampling procedure, or rather of its shortcomings.

We have not found any evidence to link the concepts measured by DPSS to personality traits, as most of the research available has been focused on the clinical application of the scale and its relation to phobias and other clinical concepts. However, disgust sensitivity as such, measured by a different scale, has been found to have a significant relationship to personality traits as defined by the Big Five paradigm. Neuroticism, for instance, has been found to correlate positively with disgust sensitivity (Druschel \& Sherman, 1999). The difference in strength of this correlation measured in sample 1 and sample 2 of our study can be explained by the fact that we have used different instruments to measure neuroticism and the fact that one sample consists of social network users and the other only out of students. The lack of correlation between Extroversion and Conscientiousness and disgust sensitivity was also reported by the previous study and corroborated by our findings as well. What is interesting is that the reported negative correlation between trait Openness and disgust sensitivity has been reported only in SFR subscale, suggesting that the weight of this relationship is located mainly in this new concept differentiated from disgust sensitivity as measured by the DPSS. Also, our findings are the first to report the existence of a negative correlation between Agreeableness and disgust sensitivity, in fact again only carried by the new SFR concept. The general low level of correlation detected is also reflects that the Big Five can explain only between $4.6 \%$ and $2.6 \%$ of the DPSS constructs variance. Overall, the described relationship between DPSS subscales and the Big Five goes hand in hand with existing results reported in literature (Druschel \& Sherman, 1999). The fact that this is so lends credence to our translation of the DPSS.

Negative affect has also been reported to have a relationship with disgust measured by the DPSS (Olatunji et al., 2007). We have found a positive correlation between all three of the proposed subscales, and this is in accordance with the findings of the above-mentioned paper, although our findings show slightly smaller $r$ values than expected. This again goes towards our belief that the Serbian translation of the DPSS is valid scale.

Disgust sensitivity has been strongly linked with various phobias, such as fear of injections and spiders and the related anxiety (Olatunji et al., 2007). Although our study did not focus on these concepts in particular, we have used general anxiety measures and factors of psychological distress and did not remain disappointed. Concepts measured by the DPSS have been found to correlate positively with general anxiety measures especially the DS subscale. On the other hand, the SFR subscale had only a weak relationship to these constructs, but as we have discussed at length before, we believe that this is due to the fact that this new concept is not developed enough. Again as before, our findings corroborate our validity claim and show that disgust sensitivity is not only related positively with specific phobias but with generalized anxiety, stress and, in minor capacity, depressiveness as well. Viewed in a different light given this relationship, we would expect that there exists a negative 
correlation between disgust sensitivity and life satisfaction, but this is not the case, as it does not correlate with this construct in any meaningful way, at last not in our sample.

We have also attempted to discover the influence of several demographic factors on disgust sensitivity and propensity. The results of ANOVA point to a difference in recorded values with regards to employment status, with those permanently employed having the lowest DS and SFR levels, but the difference in values is only significant when considering the permanently employed and students. Also, we have found no difference in any of the subscale values and education levels. Although interesting, these results can only be considered a pilot attempt, as much larger and more representative samples of the general population are needed to draw any definite conclusions. Nevertheless, these can be considered guidelines for further study.

This study regrettably suffers from several limitations. One of them is a small sample in Study 2, where we hoped that by soliciting social network users we would get a more diverse, generalized, sample of the population. Further studies will have to correct this shortcoming. Another is that we have not tested the DPSS in conjunction with some clinical construct such as phobias and specific fears. Although not crucial to the determination of the scale's validity, this does represent a shortcoming.

\section{Conclusion}

Based on the evidence made available by this study, we conclude that the Serbian translation of the DPSS scale mirrors the proposed structure of the 3-factor model, and therefore reflects literature findings. This is also true with its proposed relationship with other construct measured in our study. The lack of significant age and gender differences can be partly ascribed to the properties of the samples used in our study, but the lack of data in this area specific to DPSS also prevents comparison. We believe that the Serbian translation of the DPSS is a viable measure of the proposed construct, but must advise caution when interpreting results of the SFR subscale because it only consists of two items, and has shown low internal consistency. 


\section{References}

Akaike, H. (1987). Factor analysis and AIC. Psychometrika, 52(3), 317-332.

Al-Shawaf, L., Lewis, D. M. G., \& Buss, D. M. (2018). Sex differences in disgust: Why are women more easily disgusted than men? Emotion Review, 10(2), 149-160. https://doi.org/10.1177/1754073917709940

Bentler, P. M. (1990). Comparative fit indexes in structural models. Psychological Bulletin, 107(2), 238-246. https://doi.org/10.1037/0033-2909.107.2.238

Bostic, T. J., McGartland Rubio, D., \& Hood, M. (2000). A validation of the Subjective Vitality Scale using structural equation modeling. Social Indicators Research, 52, 313 324. https://doi.org/10.1023/A:1007136110218

Browne, M. W., \& Cudeck. R. (1993). Alternative ways of assessing model fit. In K. S. Bollen \& J. S. Long (Eds.), Testing structural equation models (pp. 136-162). Sage.

Cavanagh, K., \& Davey, G. C. (2000). The development of a measure of individual differences in disgust. British Psychology Society.

Curtis, V., Aunger, R., \& Rabie, T. (2004). Evidence that disgust evolved to protect from risk of disease. Proceedings of the Royal Sociaty B, 271, S131-S133.

de Jong, P. J., van Overveld, M., \& Peters, M. L. (2011). Sympathetic and parasympathetic responses to core disgust video clip as a function of disgust propensity and disgust sensitivity. Biological Psychology, 88(2-3), 174-179.

Diener, E., Emmons, R. A., Larsen, R. J., \& Griffin, S. (1985). The Satisfaction with Life Scale. Journal of Personality Assessment, 49(1), 71-75. https://doi.org/10.1207/ s15327752jpa4901_13

Druschel, B., \& Sherman, M., F. (1999). Disgust sensitivity as a function of the Big Five and gender. Personality and Individual Differences, 26(4), 739-748. https://doi.org/10. 1016/S0191-8869(98)00196-2

Ferguson, T. A., \& Valentiner, P. D. (2009). The Disgust Propensity and Sensitivity Scale Revised: An examination of a reduced-item version. Journal of Anxiety Disorders, 23(5), 703-710. https://doi.org/10.1016/j.janxdis.2009.02.009

Ferreira, J., Soares, S., Bem-Haja, P., Alho, L., Rocha, M., Madeira, N., \& Silva, C. (2016). Portuguese version of the Disgust Propensity and Sensitivity Scale-Revised: Preliminary data. European Psychiatry, 33(S1), S223-S224. https://doi.org/10.1016/j. eurpsy.2016.01.550

Haidt, J., McCauley, C., \& Rozin, P. (1994). Individual differences in sensitivity to disgust: A scale sampling seven domains of disgust elicitors. Personality and Individual Differences, 16(5), 701-713. https://doi.org/10.1016/0191-8869(94)90212-7

Henry, J. D., \& Crawford J. R. (2011). The short-form verstion of the Depresion Anxiety Stress Scales (DASS-21): Construct validity and normative data in a large non-clinical sample. British Journal of Clinical Psychology, 44(2), 227-239. https://doi.org/10. 1348/014466505X29657 
Goetz, A. R., Cougle, J. R., \& Lee, H.-J. (2013). Revisiting the factor structure of the 12-item Disgust Propensity and Sensitivity Scale - Revised: Evidence for the third component. Personality and Individual Differences, 55(5), 579-584. https://doi.org/10.1016/j. paid.2013.04.029

Inbar, Y., Pizarro, D. A., Knobe, J., \& Bloom, P. (2009). Disgust sensitivity predicts intuitive disapproval of gays. Emotion 9(3), 435-439. https://doi.org/10.1037/a0015960

Inbar, Y., Pizarro, D., Iyer, R., \& Heidt, J. (2012). Disgust sensitivity, political conservativism and voting. Social Psychological and Personality Science, 3(5), 537-544. https://doi.org/10.1177/1948550611429024

Iwasa, K., Tanaka, T., \& Yamada, Y. (2016). Factor structure, reliability, and validation of the Japanese version of the Disgust Propensity and Sensitivity Scale-Revised. PLOS ONE, 11(10). https://doi.org/10.1371/journal.pone.0164630

Jovanović, V. (2016). The validity of the Satisfaction with Life Scale in adolescent and a comparison with a single item satisfaction measures: A preliminary study. Quality of Life Research, 25(12), 3173-3180. https://doi.org/10.1007/s11136-016-1331-5

Jovanović, V., Gavrilov-Jerković, V., Zuljević, D., \& Brdarić, D. (2014). Psihometrijska evaluacija Skale depresivnosti, anksioznosti i stresa-21 (DASS-21) na uzorku studenata u Srbiji [Psychometric evaluation of the Depression, Anxiety and Stress-21 (DASS-21) on a sample of students in Serbia]. Psihologija, 47(1), 93-112. https://doi.org/10. 2298/PSI1401093J

Landy, J. F., \& Goodwin, G. P. (2015). Does incidental disgust amplify moral judgement? A meta-analytic review of experimental evidence. Perspectives on Psychological Science, 10(4), 518-536. https://doi.org/10.1177/1745691615583128

Landy, J. F., \& Piazza, J. (2017). Reevaluating moral disgust: Sensitivity to many affective states predicts extremity in many evaluative judgements. Social Psychological and Personality Science, 10(2), 211-219. https://doi.org/10.1177/1948550617736110

McCrae, R. R., \& Costa, R. T. (1999). A five-factor theory of personality. In L. A. Pervin \& O. P. John (Eds.), Handbook of personality: Theory and research (pp. 159-181). Guilford Press.

Medjedovic, J., \& Tara, B. (2017). The Mini IPIP-6: Short, valid, and reliable measure of the six-factor personality structure. Primenjena psihologija, 10(2), 185-202. https://doi.org/ 10.19090/pp.2017.2.185-202

Mihić, L., Novović, Z., Colović, P., \& Smederevac, S. (2014). Serbian adaptation of the Positive and Negative Affect Schedule (PANAS): Its facets and second-order structure. Psihologija, 47(4), 393-414. https://doi.org/10.2298/PSI1404393M

Miller, S. B. (2004). Disgust the gatekeeper emotion. The Analytic Press.

Mrtoni, R. M., Rancolta, P. M., Di Serio, C., \& Brombin, C. (2017). Validating the Italian version of the Disgust and Propensity Scale-Revised. Frontiers in Psychology, 8, 765. https://doi.org/10.3389/fpsyg.2017.00765. 
Nix, G. A., Ryan, R. M., Manly, J. B., \& Deci, E. L. (1999). Revitalization through selfregulation: The effects of autonomous and controlled motivation on happiness and vitality. Journal of Experimental Social Psychology, 35(3), 266-284. https://doi.org/10. 1006/jesp.1999.1382

Olatunji, B. O. (2009). Incremental specificity of disgust propensity and sensitivity in the prediction of health anxiety dimensions. Journal of Behavior Therapy and Experimental Psychiatry, 40(2), 230-239. https://doi.org/10.1016/j.jbtep.2008.10.003

Olatunji, B. O., Cisler, J. M., Deacon, B. J., Connolly, K., \& Lohr, J. M. (2007). The Disgust Propensity and Sensitivity Scale-Revised: Psychometric properties and specificity in relation to anxiety disorder symptoms. Journal of Anxiety Disorders, 21(7), 918-930. https://doi.org/10.1016/j.janxdis.2006.12.005

Olatunji, B. O., \& McKay, D. (2007). Disgust and psychiatric illness: Have we remembered. British Journal of Psychiatry, 190, 457-459. https://doi.org/10.1192/bjp.bp.106.032631

Prokop, P., \& Janciovicova, M. (2013). Disgust sensitivity and gender differences: An initial test of the parental investment hypothesis. Problems of Psychology in the 21st Century, $7,40-48$.

Rokvic, N. (2019). The validation of the Serbian version of the General Anxiety Disorder scale (GAD7): A pilot study. Engrami, 4l(2), 68-79. https://doi.org/10.5937/ engrami1902068R

Rozin, P., Haidt, J., \& McCauley, C. R. (2000). Disgust. In M. Lewis, \& J. M. Haviland-Jones (Eds.), Handbook of emotions (pp. 637-653). Guilford Press.

Rozin, P., Heidt, J., \& McCauley, C. R. (2008). Disgust: The body and soul emotion in the 21st century. In B. O. Olatunji \& D. McKay (Eds.), Disgust and it's disorders (pp. 929). American Psychological Association.

Schafer, A., Leutgeb, V., Reishofer, G., Ebner, F., \& Schienle, A. (2009). Propensity and sensitivity measured of fear and disgust are differentially related to emotion-specific brain activation. Neuroscience Letters, 465(3), 262-266. https://doi.org/10.1016/j. neulet.2009.09.030

Schnall, S., Heidt, J., Clore, G. L., \& Jortan, A. H. (2008). Disgust as embodied moral judgement. Personality and Social Psychology Bulletin, 34(8), 1096-1109. https://doi.org/10.1177/0146167208317771

Schwarz, G. E. (1978). Estimating the dimension of a model. Annals of Statistics, 6(2), 461464. https://doi.org/10.1214/aos/1176344136

Shook, N. J., Ford, C. G., \& Boggs, S. T. (2017). Dangerous worldview: A mediator of the relation between disgust sensitivity and social conservativism. Personality and Individual Differences, 119, 252-261. https://doi.org/10.1016/j.paid.2017.07.027

Sibley, C. G. (2012). The Mini-IPIP6: Item Response Theory analysis of a short measure of the big-six factors of personality in New Zealand. New Zealand Journal of Psychology, 41(3), 21-30. 
Spitzer, R. L., Kroenke, K., \& Williams, J. B. W. (2006). A brief measure for assesing generalized anxiety disorder, The GAD7. Archives of Internal Medicine, 166(10), 10921097. https://doi.org/10.1001/archinte.166.10.1092

Travis, R., \& Fergus, T. A. (2015). The potentiating effect of disgust sensitivity on the relationship between disgust propensity and mental contamination. Journal of Obsessive-Compulsive and Related Disorders, 6, 114-119. https://doi.org/10.1016/j. jocrd.2015.06.007

Tucker, L. R., \& Lewis, C. (1973). A reliability coefficient for maximum likelihood factor analysis. Psychometrika, 38(1), 1-10. https://doi.org/10.1007/BF02291170

Tybar, J. M., Lieberman, D., \& Griskevicius, L. (2019). Microbes, mating, and morality: Individual differences in three functional domains of disgust. Journal of Personality and Social Psychology, 97(1), 103-112. https://doi.org/10.1037/a0015474

van Overveld, M., de Jong, P., Peters, M. L., van Hout, W. J., \& Bouman, T. K. (2008). An internet-based study on the relation between disgust sensitivity and emetophobia. Journal of Anxiety Disorders, 22(3), 524-531. https://doi.org/10.1016/j.janxdis. 2007. 04.001

van Overveld, W. J., de Jong, P. J., Peters, M. L., Cavanagh, K., \& Davey, G. C. (2006). Disgust propensity and disgust sensitivity: Separate constructs that are differentially related to specific fears. Personality and Individual Differences, 41(7), 1241-1252. https://doi.org/10.1016/j.paid.2006.04.021

Vasić, A., Sarcević, D., \& Trogrlić, A. (2011). Zadovoljstvo životom u Srbiji [Life satisfaction in Serbia]. Primenjena psihologija, 4(2), 151-177. https://doi.org/10. 19090/pp.2011.2.151-177

Vicario, C. M., Rafal, R. D., Martino, D., \& Avenanti, A. (2017). Core, social and moral disgust are bounded: A review on behavioral and neural basis of repugnance in clinical disorders. Neuroscience and Behavioral Reviews, 80, 185-200. https://doi.org/10. 1016/j.neubiorev.2017.05.008

von Spreckelsen, P., Glashouwer, K. A., Bennik, E. C., Wessel, I., \& de Jong, P. J. (2018). Negative body image: Relationship with heightened disgust propensity, disgust sensitivity and self-directed disgust. PLOS ONE, 13(6). https://doi.org/10.1371/ journal.pone.0198532

Wagemans, F., Brandt, M. J., \& Zeelenbers, M. (2019). Weirdness of disgust sensitivity items predicts their relationship to purity moral judgments. Personality and Individual Differences, 146, 182-187. https://doi.org/10.1016/j.paid.2018.07.042

Watson, D., Clark, L. A., \& Carey, G. (1988). Positive and negative affectivity and their relation to anxiety and depressive disorders. Journal of Abnormal Psychology, 97(3), 346-353. https://doi.org/10.1037/0021-843X.97.3.346 


\title{
Validacija srpskoga prijevoda Skale sklonosti gađenju i osjetljivosti na gađenje
}

\begin{abstract}
Sažetak
Gađenje predstavlja osjećaj odbojnosti koji se pojavljuje kao odgovor na neugodne podražaje te je indikator motivacije izbjegavanja podražaja. Nekoliko je pokušaja mjerenja gađenja, a prve su razvijene skale Skala osjetljivosti na gađenje (Haidt i sur., 1994), koja se temelji na odgovorima na izazivače gađenja, i Skala sklonosti gađenju i osjetljivosti na gađenje (DPSS, Cavanagh i Davey, 2000), koja se više usmjerava na sam osjećaj gađenja, a manje na jačinu reakcije na specifične izazivače gađenja. Dva su predložena modela skale DPSS. Prema jednome modelu DPSS ima dvije podljestvice, sklonost gađenju (DP) i osjetljivost na gađenje (DS), dok se prema drugome modelu skala sastoji od triju podljestvica, odnosno skala osjetljivosti na gađenje sadrži još i samofokusirano/ruminirajuće gađenje (SFR). Cilj je provedenoga istraživanja bio validirati srpsku verziju skale DPSS. Istraživanje je provedeno na dvama uzorcima: na uzorku studenata $(N=437)$ i na uzorku prikupljenome putem društvenih mreža $(N=344)$. Na obama su uzorcima rezultati konfirmatorne faktorske analize pokazali bolje indekse pristajanja trofaktorskoga rješenja. Pouzdanost tipa unutarnje konzistencije bila je granično prihvatljiva, pri čemu je bila niža za podljestvicu SFR na uzorku studenata. Dobivene spolne razlike u skladu su s postavljenim hipotezama. Također, podljestvice sklonosti gađenju i osjetljivosti na gađenje bile su u niskim pozitivnim korelacijama s Neuroticizmom, negativnim afektom, stresom, depresivnošću i anksioznošću, što ide u prilog valjanosti skale. Zaključno, smatramo da je srpska verzija Skale sklonosti gađenju i osjetljivosti na gađenje od 12 čestica primjerena za korištenje u budućim istraživanjima te teme.
\end{abstract}

Ključne riječi: osjetljivost na gađenje, sklonost gađenju, DPSS, validacija

Primljeno: 1. 3. 2020. 
Supplement 1. The Serbian Version of the DPSS-R

\begin{tabular}{|c|c|c|c|c|c|}
\hline & $\begin{array}{l}\text { Nije } \\
\text { tačno }\end{array}$ & & $\begin{array}{c}\text { Nisam } \\
\text { siguran/a }\end{array}$ & & $\begin{array}{l}\text { Potpuno } \\
\text { tačno }\end{array}$ \\
\hline Izbegavam gadne/odvratne stvari. & 1 & 2 & 3 & 4 & 5 \\
\hline $\begin{array}{l}\text { Kada osetim gađenje uplašim se da ću } \\
\text { možda pasti u nesvest. }\end{array}$ & 1 & 2 & 3 & 4 & 5 \\
\hline Uplašim se kada osetim mučninu. & 1 & 2 & 3 & 4 & 5 \\
\hline Osetim odbojnost. & 1 & 2 & 3 & 4 & 5 \\
\hline $\begin{array}{l}\text { Od gadnih/odvratnih stvari mi se okrene } \\
\text { stomak. }\end{array}$ & 1 & 2 & 3 & 4 & 5 \\
\hline $\begin{array}{l}\text { Napravim grimasu kada mi se nešto } \\
\text { gadi/mi je odvratno. }\end{array}$ & 1 & 2 & 3 & 4 & 5 \\
\hline $\begin{array}{l}\text { Kada shvatim da osećam mučninu, } \\
\text { uplašim se da ću možda povratiti. }\end{array}$ & 1 & 2 & 3 & 4 & 5 \\
\hline $\begin{array}{l}\text { U stanju sam da osetim } \\
\text { gađenje/odvratnost. }\end{array}$ & 1 & 2 & 3 & 4 & 5 \\
\hline Uplaši me kada osetim nesvesticu. & 1 & 2 & 3 & 4 & 5 \\
\hline Nalazim da je nešto gadno/odvratno. & 1 & 2 & 3 & 4 & 5 \\
\hline $\begin{array}{l}\text { Sramota me je kada mi se nešto gadi/mi } \\
\text { je odvratno. }\end{array}$ & 1 & 2 & 3 & 4 & 5 \\
\hline $\begin{array}{l}\text { Nije dobro za mene kada osetim } \\
\text { gađenje/odvratnost. }\end{array}$ & 1 & 2 & 3 & 4 & 5 \\
\hline
\end{tabular}

